\title{
Żaneta Gwardzińska
}

\section{Informacja o książce pt. Restytucja i ochrona dóbr kultury. Zagadnienia prawne red. Iwona Gredka-Ligarska, Anna Rogacka-Łukasik}

ISBN 978-83-65682-76-5

Oficyna Wydawnicza „Humanitas”, Sosnowiec 2017

W 2017 r. nakładem Oficyny Wydawniczej „Humanitas” ukazała się monografia pt. Restytucja i ochrona dóbr kultury. Zagadnienia prawne. Zwrot dóbr kultury wyprowadzonych niezgodnie z prawem z terytorium państwa członkowskiego na podstawie Dyrektywy 2014/60/UE z dnia 15.05.2014 r., będąca pracą zbiorową pod redakcją naukową Iwony Gredki-Ligarskiej i Anny Rogackiej-Łukasik.

Rozważania zamieszczone w publikacji koncentrują się głównie na zagadnieniach związanych z restytucją dóbr kultury, analizowaną przez pryzmat dyrektywy Parlamentu Europejskiego i Rady 2014/60/UE z dnia 15 maja 2014 r. w sprawie zwrotu dóbr kultury wyprowadzonych niezgodnie z prawem z terytorium państwa członkowskiego, zmieniającej rozporządzenie (UE) nr 1024/2012 (dalej: dyrektywa 2014/60/UE).

W rozdziale pierwszym, zatytułowanym Odzyskiwanie utraconych dóbr kultury z perspektywy wyrażonej w art. 6 Konstytucji RP zasady ochrony dziedzictwa kulturowego, Maciej Borski zaprezentował problematykę ochrony dziedzictwa kulturowego w ujęciu prawnoporównawczym oraz historycznym, a także przybliżył podstawowe pojęcia użyte w art. 6 Konstytucji RP, takie jak: dobro kultury, kultura, narodowe dziedzictwo 
kulturowe. Autor zgłosił również postulat uchwalenia aktu prawnego (np. ustawy Prawo dóbr kultury), który w sposób jednolity, spójny i wyczerpujący uregulowałby tematykę związaną z dobrami kultury, ich ochroną i korzystaniem z tych dóbr.

W rozdziale drugim, pt. Państwowy zasób archiwalny, Dorota Fleszer omówiła problematykę dbałości o archiwalia, będącej przejawem ochrony dziedzictwa narodowego i budowania tożsamości narodowej. Analizie poddano podstawowe pojęcia z zakresu kształtowania zasobu archiwalnego, a mianowicie: materiał archiwalny oraz narodowy i państwowy zasób archiwalny. Zauważona została również konieczność ochrony zasobów wytwarzanych przez inne podmioty, które dzięki swojej aktywności w przestrzeni publicznej wy wierają wpływ na sytuację polityczną, gospodarczą i społeczną państwa.

W rozdziale trzecim, pt. Regionalne systemy ochrony dziedzictwa kulturowego przed nielegalnym wywozem. Analiza krytyczna, Andrzej Jakubowski poruszył problematykę ochrony dziedzictwa kulturowego przed nielegalnym wywozem jako ugruntowanej zasady prawa międzynarodowego. Celem rozważań było wskazanie roli reżimu konwencji paryskiej z $1970 r^{1}{ }^{1}$ w standaryzacji mechanizmów ochrony dóbr kultury przed zagrożeniami związanymi z nielegalnym eksportem na gruncie regionalnych instrumentów prawnej ochrony dziedzictwa. W tym kontekście została wskazana specyfika poszczególnych reżimów regionalnych i charakter obowiązków spoczywających na wybranych przez A. Jakubowskiego państwach członkowskich i organizacjach międzynarodowych.

Czwarty rozdział książki, zatytułowany Wpływ Dyrektywy Parlamentu Europejskiego i Rady 2014/60/UE z dnia 15 maja 2014 r. w sprawie zwrotu dóbr kultury wyprowadzonych niezgodnie z prawem z terytorium państwa członkowskiego na kontrole obrotu dobrami kultury w Niemczech, autorstwa Olgierda Jakubowskiego, przybliża ewolucję systemu prawnej ochrony dóbr kultury w Niemczech. Komentując nową niemiecką ustawę o ochronie dóbr kultury (niem. Kulturgutschutzgesetz), autor dokonał analizy przepisów prawnych dotyczących wwozu i wywozu dóbr kultury oraz kontroli obrotu dobrami kultury w Niemczech.

W rozdziale piątym, pt. Wykonanie orzeczenia nakazujacego zwrot dobra kultury na terytorium państwa członkowskiego UE w świetle Dyrektywy 2014/60/UE, Iwona Gredka-Ligarska przeprowadziła analizę trybu wykonywania orzeczeń sądów polskich, nakazujących zwrot dobra kultury na terytorium państwa członkowskiego UE w świetle dyrektywy 2014/60/UE. Autorka przedstawiła krytyczne uwagi dotyczące procedury zwrotu dóbr kultury na terytorium państwa członkowskiego UE, przewidzianej w ustawie $z$ dnia 25 maja 2017 r. o restytucji narodowych dóbr kultury (Dz. U. z 2017 r., poz. 1086 oraz z 2018 r., poz. 770). Zdaniem autorki, sposób egzekucji zaproponowany przez polskiego ustawodawcę $w$ ustawie imple-

1 Konwencja dotycząca środków zmierzających do zakazu i zapobiegania nielegalnemu przywozowi, wywozowi i przenoszeniu własności dóbr kultur, sporządzona w Paryżu w dniu 17 listopada 1970 r., Dz.U. z 1974 r. Nr 20, poz. 106. 


\section{PUBLIKACJE}

Żaneta Gwardzińska

mentującej dyrektywę 2014/60/UE do systemu prawa polskiego nie jest trafnym rozwiązaniem, dlatego sformułowała ona propozycje wniosków de lege ferenda dotyczące procedury wykonywania orzeczeń polskich sądów nakazujących zwrot dobra kultury na terytorium państwa członkowskiego UE.

W rozdziale szóstym, zatytułowanym System Internal Market Information jako narzędzie służące odzyskaniu skradzionych lub wyprowadzonych niezgodnie z prawem dóbr kultury, Anna Rogacka-Łukasik scharakteryzowała nowy system wymiany informacji na rynku wewnętrznym, tj. System Internal Market Information. Autorka przedstawiła również zasady funkcjonowania systemu wynikające z rozporządzenia Parlamentu Europejskiego i Rady (UE) nr 1024/2012 z dnia 25 października 2012 r. w sprawie współpracy administracyjnej za pośrednictwem systemu wymiany informacji na rynku wewnętrznym i uchylające decyzję Komisji 2008/49/WE.

Monografię kończy rozdział siódmy, zatytułowany Bezpieczeństwo informacji przetwarzanych w systemie International Market Information, w którym Żaneta Gwardzińska zawarła rozważania koncentrujące się na prawnych aspektach bezpieczeństwa informacji przetwarzanych w systemie International Market Information (IMI), ze szczególnym uwzględnieniem ochrony danych osobowych przetwarzanych w tym systemie. Obecnie bowiem problematyka bezpieczeństwa informacji przetwarzanych w systemach teleinformatycznych stanowi kluczowy punkt rozważań dotyczących bezpieczeństwa wewnętrznego organizacji działających w cyberrzeczywistości. 